\title{
KEMAMPUAN MATEMATIS MAHASISWA DALAM PENERAPAN ASESMEN KOLABORATIF
}

\author{
Himmatul Ulya ${ }^{1}$, Ratri Rahayu ${ }^{2}$, Kartono $^{3}$, dan Isnarto $^{4}$ \\ ${ }^{1,2}$ Program Studi Pendidikan Matematika, Universitas Muria Kudus \\ ${ }^{3,4}$ Jurusan Matematika, Universitas Negeri Semarang \\ Email: himmatul.ulya@umk.ac.id
}

\section{Info Artikel}

Sejarah Artikel:

Diserahkan 6 November 2019

Direvisi 18 November 2019

Disetujui 28 November 2019

\section{Keywords:}

collaborative assessment,

ethnomathematics,

mathematics ability,

\begin{abstract}
This study aims to describe the ability to understand concepts, communication, connections, reasoning, problem solving, critical thinking, and mathematical creative thinking of PGSD students in Ethnomatematics courses.

The subjects of this study were 6th semester students of the Elementary Teacher Education Program Universitas Muria Kudus (PGSD UMK) in the 2018/2019 school year. This type of research is a quantitative descriptive study. Data collection in this study used test techniques. The instrument used was a test to measure students' mathematical abilities. Data analysis was performed descriptively to determine the profile of students' mathematical abilities and the distribution of achievement achievements in each of the measured mathematical abilities.

The results showed that: (1) the average mathematical concept understanding ability of $P G S D$ students reached an average of 88.44 with the predicate $A ;(2)$ the average mathematical communication ability of students reaches 74.54 with the predicate $B$; (3) the average mathematical connection ability of students reaches 10.63 with the predicate E; (4) the average mathematical reasoning ability of students gained 36.93 with the predicate $D$; (5) the average mathematical problem solving ability of students reached 76.28 with the predicate $A B ;(6)$ the average mathematical critical thinking ability of students reaches 77.56 with the predicate $A B$; and (7) the average mathematical creative thinking ability of students reaches 64.83 with the predicate of $B C$.
\end{abstract}

\begin{abstract}
Abstrak
Penelitian ini bertujuan untuk mendeskripsikan kemampuan pemahaman konsep, komunikasi, koneksi, penalaran, pemecahan masalah, berpikir kritis, dan berpikir kreatif matematis mahasiswa PGSD pada mata kuliah Etnomatematika.

Subjek penelitian ini yaitu mahasiswa semester 6 Program Studi Pendidikan Guru Sekolah Dasar Universitas Muria Kudus (PGSD UMK) tahun ajaran 2018/2019. Jenis penelitian ini merupakan penelitian deskriptif kuantitatif. Pengumpulan data dalam penelitian ini menggunakan teknik tes. Instrumen yang digunakan yaitu tes uraian untuk mengukur kemampuan matematis mahasiswa. Analisis data dilakukan secara deskriptif untuk mengetahui profil kemampuan matematis mahasiswa dan distribusi pencapaian predikat pada setiap kemampuan matematis yang diukur.

Hasil penelitian menunjukkan bahwa: (1) rata-rata kemampuan pemahaman konsep matematis mahasiswa PGSD mencapai rata-rata 88,44 dengan predikat A; (2) rata-rata kemampuan komunikasi matematis mahasiswa mencapai 74,54 dengan predikat B; (3) ratarata kemampuan koneksi matematis mahasiswa mencapai 10,63 dengan predikat E; (4) rata-rata kemampuan penalaran matematis mahasiswa memperoleh nilai 36,93 dengan predikat D; (5) rata-rata kemampuan pemecahan masalah matematis mahasiswa mencapai 76,28 dengan predikat $\mathrm{AB}$; (6) rata-rata kemampuan berpikir kritis matematis mahasiswa mencapai 77,56 dengan predikat $\mathrm{AB}$; dan (7) rata-rata kemampuan berpikir kreatif matematis mahasiswa mencapai 64,83 dengan predikat $\mathrm{BC}$.
\end{abstract}

(C) 2019 Universitas Muria Kudus 


\section{PENDAHULUAN}

Berpikir secara matematis memberikan banyak manfaat bagi seluruh kegiatan seseorang. Dengan demikian, seseorang hendaknya memiliki kemampuan matematis yang baik agar mampu memecahkan berbagai masalah dalam kehidupan sehari-harinya. Kemampuan berpikir matematis merupakan modal dasar dalam pembelajaran bermakna di abad 21 ini. Kemampuan berpikir matematis tingkat tinggi perlu dioptimalkan di dalam pembelajaran guna melaksanakan prinsip-prinsip pembelajaran dalam Kurikulum 2013 (Fajri, 2017).

Pada pembelajaran matematika seharusnya perlu ditekankan pada berbagai kemampuan matematis, sehingga siswa tidak kesulitan jika menemui berbagai permasalahan matematis dalam kehidupan. Pada kenyataannya, dalam pembelajaran matematika guru belum pernah merencanakan maupun melaksanakan pembelajaran yang menekankan kemampuan dan keterampilan berpikir yang lebih tinggi dalam menyelesaikan masalah (Musfiqi \& Jailani, 2014). Pembelajaran matematika berfokus pada pemahaman konsep matematis yang merupakan kemampuan paling dasar dari kemampuan matematis. Kemampuan pemahaman konsep matematis tergolong penting, tetapi mahasiswa akan kesulitan jika tidak diimbangi dengan pembiasaan dalam memecahkan masalah nyata yang terkandung di dalam berbagai kemampuan matematis. Kemampuan-kemampuan matematis yang perlu dikembangkan dan dimiliki oleh mahasiswa yaitu kemampuan komunikasi matematis, koneksi matematis, penalaran matematis, pemecahan masalah matematis, berpikir kritis matematis, dan berpikir kreatif matematis (Sumarmo, 2012).

Dalam rangka mengembangkan kemampuan matematis yang harus dimiliki mahasiswa, dosen dapat melakukan pembelajaran matematika secara bermakna. Pembiasaan dalam memecahkan masalah matematis dalam kehidupan sehari-hari dapat dilakukan dengan pemberian soal-soal matematika yang dikaitkan dengan budaya dan lingkungan sekitar di dalam pembelajaran. Selain pembelajaran yang bermakna, asesmen juga perlu disiapkan secara matang oleh dosen agar capaian pembelajaran dapat diraih maksimal oleh mahasiswa.

Selain proses pada pembelajaran, asesmen juga salah satu aspek penting dalam pembelajaran (Khodabakhshzadeh, Kafi, \&
Hosseinnia, 2018). Tanpa adanya asesmen, pembelajaran tidak dapat diukur keberhasilannya. Asesmen merupakan bahan untuk melaporkan kemajuan hasil belajar dan dapat digunakan sebagai masukan untuk evaluasi proses pembelajaran. Kemampuan pendidik dalam mengembangkan, melaksanakan, dan melakukan analisis hasil adalah kunci antara kualitas asesmen dengan pencapaian siswa (Ashraf \& Zolfaghari, 2018).

Idealnya di dalam proses asesmen terdapat keterlibatan antara dosen dan mahasiswa. Faktanya mahasiswa tidak dilibatkan dalam asesmen pada pembelajaran matematika (Kartono, Winarti, \& Masrukan, 2016). Asesmen yang dilakukan selama ini hanya sepihak dari pendidik. Jika hal ini terjadi secara kontinu, maka akan berimbas pada capaian pembelajaran mahasiswa. Selain itu, ketidakterlibatan mahasiswa dalam asesmen bertolak belakang dengan standar penilaian pembelajaran dalam Standar Nasional Perguruan Tinggi di Indonesia (SNPT). Di dalam standar tersebut dijelaskan bahwa pelaksanaan penilaian dilakukan dengan dosen pengampu dengan mengikutsertakan mahasiswa di dalam seluruh prosesnya (Kemenristekdikti, 2015)

Penilaian akhir matematika dalam tes akhir semester tidak secara kesuluruhan menunjukkan kemampuan matematis peserta didik (Joseph, 2011). Penilaian yang dilakukan dosen sebatas menilai kemampuan menghafal dan mengingat fakta dan tidak menilai pemikiran tingkat tinggi (Dandis, 2013). Asesmen dalam matematika perlu ditekankan pada kecakapan untuk menyelesaikan permasalahanpermasalahan non-rutin (Sumaryanta, 2018). Penilaian yang rutin tidak mendorong kreativitas dan inovasi peserta didik sehingga strategi pembelajaran dan penilaian konvensional akan menciptakan jarak antara mahasiswa dan dosen dalam menyukseskan pembelajaran.

Berdasarkan hasil studi pendahuluan, mahasiswa PGSD UMK belum dilibatkan dalam pengembangan asesmen. Mahasiswa hanya pemakai asesmen tanpa dilibatkan dalam diskusi dan melakukan kesepakatan mengenai kriteria asesmen yang akan digunakan. Hal ini menyebabkan mahasiswa tidak dapat menyumbangkan pemikiran dan aspirasinya dalam asesmen dan terdapat kontradiksi dengan standar penilaian dalam SNPT. Selain itu, penilaian pada pembelajaran etnomatematika tidak mengukur kemampuan berpikir tingkat 
tinggi. Soal yang dibuat hanya seputar mengukur pemahaman matematis yang mengutamakan pengerjaan secara mekanik (R. Rahayu, Ulya, Kartono, Isnarto, \& Kurniasih, 2018).

Berdasarkan hasil studi pendahuluan maka perlu dikembangkan inovasi asesmen agar kualitas pembelajaran dan asesmen semakin baik. Inovasi asesmen yang dilakukan yaitu dengan melakukan pengembangan model asesmen pada pembelajaran etnomatematika yang melibatkan mahasiswa dalam proses dan pelaksanaannya. Penilaian dengan melibatkan mahasiswa merupakan salah satu alternatif dari penilaian menggunakan asesmen kolaboratif. Asesmen kolaboratif dapat dilakukan dengan melibatkan mahasiswa dalam diskusi dan melakukan kesepakatan mengenai kriteria asesmen yang akan diterapkan (Falchikov, 2005). Selain itu, penilaian matematika seyogyanya dilakukan untuk mengukur seluruh kemampuan matematis mahasiswa agar tidak berfokus pada penilaian pada berpikir matematis tingkat rendah.

Asesmen kolaboratif dalam penelitian ini diterapkan dengan instrumen soal yang berkaitan dengan etnomatematika. Etnomatematika yaitu semua bentuk penjelasan dan pemahaman matematika yang dirumuskan dan dikaitkan dengan kelompok budaya (Rosa \& Orey, 2011). Kaitan masalah dengan budaya dan lingkungan sehari-harinya akan mempermudah mahasiswa untuk memahami matematika. Jika dalam pembelajaran matematika dikaitkan dengan budaya akan menjadikan pembelajaran matematika lebih efektif untuk meningkatkan kemampuan matematis siswa (Arisetyawan, Suryadi, Herman, \& Rahmat, 2014).

Berdasarkan hasil penelitian sebelumnya mengenai uji kelayakan model asesmen kolaboratif ditinjau dari kejelasan prosedur, validitas instrumen, kejelasan panduan, dan kekomprehensifan komponen asesmen diperoleh hasil bahwa model asesmen kolaboratif pada pembelajaran etnomatematika yang dikembangkan dinyatakan layak untuk digunakan.

Kepraktisan model asesmen kolaboratif yang dinilai dengan menggunakan angket respon mahasiswa, guru, dan dosen menunjukkan respon positif. Berdasarkan penelitian sebelumnya menunjukkan hasil bahwa sebesar $87,35 \%$ mahasiswa memberikan respon positif. Guru dan dosen juga memberikan respon positif terhadap model asesmen kolaboratif dengan rata- rata hasil angket respon guru dan dosen berturutturut adalah 3,50 dan 3,65 pada kategori sangat baik. Hasil ini mengindikasikan bahwa model asesmen kolaboratif pada mata kuliah etnomatematika yang dikembangkan dinyatakan praktis untuk digunakan (Ratri Rahayu, Ulya, Kartono, \& Isnarto, 2019).

Model asesmen kolaboratif pada pembelajaran etnomatematika yang layak digunakan dan mendapat respon positif dari mahasiswa, guru, dan dosen selanjutnya digunakan sebagai instrumen untuk mengukur kemampuan matematis mahasiswa. Pengukuran kemampuan matematis mahasiswa ini bertujuan agar guru dapat mengetahui sejauh mana kemampuan mahasiswa dan dapat digunakan sebagai pedoman untuk memperbaiki kesalahan dalam menyelesaikan masalah, serta memperbaiki proses pembelajaran. Berdasarkan hal tersebut, maka penelitian ini bertujuan untuk mendeskripsikan kemampuan pemahaman konsep matematis, kemampuan komunikasi matematis, kemampuan koneksi matematis, kemampuan penalaran matematis, kemampuan pemecahan masalah matematis, kemampuan berpikir kritis matematis, dan kemampuan berpikir kreatif matematis mahasiswa PGSD pada mata kuliah Etnomatematika.

\section{METODE PENELITIAN}

Penelitian ini dilakukan pada semester genap dengan subjek penelitiannya yaitu mahasiswa semester 6 Program Studi Pendidikan Guru Sekolah Dasar FKIP Universitas Muria Kudus (PGSD FKIP UMK) tahun ajaran 2018/2019. Jenis penelitian ini merupakan penelitian deskriptif kuantitatif. Pendekatan deskriptif kuantitatif digunakan karena dalam penelitian ini bertujuan untuk mendeskripsikan suatu data dalam penelitian dan memotret suatu kondisi (Rasi et al., 2017; Williams, 2007). Kondisi yang dianalisis dalam penelitian ini yaitu kemampuan matematis mahasiswa.

Pengumpulan data dalam penelitian ini menggunakan teknik tes. Instrumen yang digunakan untuk mengumpulkan data yaitu tes untuk mengukur kemampuan matematis mahasiswa berbentuk uraian. Instrumen tes kemampuan pemahaman konsep matematis terdiri dari 10 soal, tes kemampuan komunikasi matematis terdiri dari 10 soal, tes kemampuan koneksi matematis terdiri dari 10 soal, tes kemampuan penalaran matematis terdiri dari 10 soal, tes kemampuan pemecahan masalah 
Himmatul Ulya, Ratri Rahayu, Kartono, dan Isnarto

KEMAMPUAN MATEMATIS MAHASISWA DALAM PENERAPAN ASESMEN KOLABORATIF

REFLEKSI EDUKATIKA : Jurnal Ilmiah Kependidikan 10 (1) Desember 2019. Hlm.113-120

matematis terdiri dari 8 soal, tes kemampuan berpikir kritis matematis terdiri dari 10 soal, dan tes kemampuan berpikir kreatif matematis terdiri dari 10 soal. Setiap tes kemampuan matematis diberikan kepada 134 mahasiswa PGSD UMK. Instrumen soal yang digunakan telah memenuhi seluruh indikator kemampuan matematis. Selain itu, instrumen telah diujicobakan sehinga memenuhi kriteria valid dan reliabel.

Data hasil tes mahasiswa kemudian dianalisis secara deskriptif untuk mengetahui profil kemampuan matematis mahasiswa dan distribusi pencapaian predikat pada setiap kemampuan matematis yang diukur. Deskripsi distribusi predikat kemampuan matematis mahasiswa mengacu pada predikat yang digunakan di PGSD UMK, yaitu nilai $85 \leq \mathrm{A} \leq$ $100,75 \leq \mathrm{AB}<85,67 \leq \mathrm{B}<75,61 \leq \mathrm{BC}<67$, $55 \leq \mathrm{C}<61,45 \leq \mathrm{CD}<55,35 \leq \mathrm{D}<45$, dan $0 \leq$ $\mathrm{E}<35$.

\section{HASIL DAN PEMBAHASAN}

Tes kemampuan matematis yang telah diujikan kepada 134 mahasiswa memberikan hasiol sebagai berikut.

\section{Profil Kemampuan Pemahaman Konsep Matematis Mahasiswa \\ Nilai terendah dari tes kemampuan pemahaman konsep matematis yaitu 0 , sedangkan nilai tertinggi mencapai nilai 100 . Secara rinci profil kemampuan pemahaman konsep matematis mahasiswa berdasarkan predikatnya disajikan pada Tabel 1 berikut.}

Tabel 1. Profil Kemampuan Pemahaman Konsep Matematis Mahasiswa

\begin{tabular}{ccc}
\hline Nilai & Predikat & $\begin{array}{c}\text { Banyak } \\
\text { Mahasiswa }\end{array}$ \\
\hline $85 \leq$ nilai $\leq 100$ & $\mathrm{~A}$ & 111 \\
$75 \leq$ nilai $<85$ & $\mathrm{AB}$ & 0 \\
$67 \leq$ nilai $<75$ & $\mathrm{~B}$ & 4 \\
$61 \leq$ nilai $<67$ & $\mathrm{BC}$ & 4 \\
$55 \leq$ nilai $<61$ & $\mathrm{C}$ & 0 \\
$45 \leq$ nilai $<55$ & $\mathrm{CD}$ & 1 \\
$35 \leq$ nilai $<45$ & $\mathrm{D}$ & 2 \\
$0 \leq$ nilai $<35$ & $\mathrm{E}$ & 12 \\
\hline
\end{tabular}

Mahasiswa dikatakan memenuhi kriteria ketuntasan belajar jika memperoleh nilai $\geq 55$, atau minimal memperoleh predikat $\mathrm{C}$. Berdasarkan Tabel 1, mahasiswa yang kemampuan pemahaman konsep matematisnya tuntas berjumlah 119, sedangkan 15 mahasiswa tidak mencapai ketuntasan belajar minimalnya. Secara klasikal, rata-rata kemampuan pemahaman konsep matematis mahasiswa yaitu 88,44 . Hal ini berarti rata-rata kemampuan pemahaman konsep matematis mahasiswa secara klasikal masuk dalam predikat A.

Soal-soal yang digunakan untuk mengukur kemampuan pemahaman konsep matematis menggunakan soal etnomatematika. Etnomatematika yang dimaksud yaitu konten permasalahan matematika dihubungkan dengan budaya (Fouze \& Amit, 2018). Hal ini memudahkan mahasiswa untuk memahami permasalahan dan konsep matematika (Ulya, 2016).

\section{Profil Kemampuan Komunikasi Matematis Mahasiswa}

Nilai terendah dari tes kemampuan komunikasi matematis adalah 0 , sedangkan nilai tertingginya mencapai angka 100 . Secara rinci profil kemampuan komunikasi matematis mahasiswa berdasarkan predikatnya disajikan pada Tabel 2 berikut.

Tabel 2. Profil Kemampuan Komunikasi Matematis Mahasiswa

\begin{tabular}{ccc}
\hline Nilai & Predikat & $\begin{array}{c}\text { Banyak } \\
\text { Mahasiswa }\end{array}$ \\
\hline $85 \leq$ nilai $\leq 100$ & A & 68 \\
$75 \leq$ nilai $<85$ & AB & 13 \\
$67 \leq$ nilai $<75$ & B & 20 \\
$61 \leq$ nilai $<67$ & BC & 5 \\
$55 \leq$ nilai $<61$ & C & 2 \\
$45 \leq$ nilai $<55$ & CD & 5 \\
$35 \leq$ nilai $<45$ & D & 3 \\
$0 \leq$ nilai $<35$ & E & 18 \\
\hline
\end{tabular}

Berdasarkan Tabel 2, mahasiswa yang kemampuan komunikasi matematisnya tuntas berjumlah 108, sedangkan 26 mahasiswa tidak mencapai ketuntasan belajar minimalnya. Kemampuan komunikasi matematis mahasiswa secara klasikal mencapai rata-rata 74,54. Hal ini berarti rata-rata kemampuan komunikasi matematis mahasiswa secara klasikal masuk dalam predikat $\mathrm{B}$.

Dalam mengerjakan soal kemampuan komunikasi matematis, mahasiswa mengalami kesulitan dalam indikator membuat konjektur, menyusun argumen, merumuskan definisi atau generalisasi. Hal ini tidak sesuai dengan hasil penelitian yang menyatakan bahwa siswa menemui kendala dan melakukan kesalahan 
Himmatul Ulya, Ratri Rahayu, Kartono, dan Isnarto

KEMAMPUAN MATEMATIS MAHASISWA DALAM PENERAPAN ASESMEN KOLABORATIF

REFLEKSI EDUKATIKA : Jurnal Ilmiah Kependidikan 10 (1) Desember 2019. Hlm.113-120

ketika mengubah permasalahan ke dalam notasi dan simbol matematika (Wijayanto, Fajriah, \& Anita, 2018).

Rata-rata kemampuuan komunikasi matematis mahasiswa telah mencapai predikat baik. Mahasiswa sudah dapat menyelesaikan permasalahan sesuai dengan indikator komunikasi matematis, tetapi masih belum sistematis dalam membuat kalimat dalam menyelesaikan permasalahan. Menyusun penyelesaian secara sistematis pada mahasiswa perlu dikembangkan lagi mengingat berkomunikasi dalam matematika diharapkan dapat menjadi sebuah kebiasaan baik yang perlu dimiliki dalam berkehidupan bermasyarakat (Umar, 2012).

\section{Profil Kemampuan Koneksi Matematis Mahasiswa}

Tes kemampuan koneksi matematis diberikan kepada 134 mahasiswa. Pada tes ini, nilai terendah yang diperoleh mahasiswa adalah 0 , sedangkan nilai tertingginya yaitu 95 . Secara rinci profil kemampuan koneksi matematis mahasiswa berdasarkan predikatnya disajikan pada Tabel 3 berikut.

Tabel 3. Profil Kemampuan Koneksi Matematis Mahasiswa

\begin{tabular}{ccc}
\hline Nilai & Predikat & $\begin{array}{c}\text { Banyak } \\
\text { Mahasiswa }\end{array}$ \\
\hline $85 \leq$ nilai $\leq 100$ & $\mathrm{~A}$ & 2 \\
$75 \leq$ nilai $<85$ & $\mathrm{AB}$ & 0 \\
$67 \leq$ nilai $<75$ & $\mathrm{~B}$ & 0 \\
$61 \leq$ nilai $<67$ & $\mathrm{BC}$ & 1 \\
$55 \leq$ nilai $<61$ & $\mathrm{C}$ & 0 \\
$45 \leq$ nilai $<55$ & $\mathrm{CD}$ & 3 \\
$35 \leq$ nilai $<45$ & $\mathrm{D}$ & 1 \\
$0 \leq$ nilai $<35$ & $\mathrm{E}$ & 127 \\
\hline
\end{tabular}

Berdasarkan Tabel 3, mahasiswa yang kemampuan koneksi matematisnya tuntas berjumlah 3 mahasiswa, sedangkan 131 mahasiswa tidak mencapai ketuntasan belajar minimalnya. Secara klasikal, kemampuan koneksi matematis mahasiswa mencapai rata-rata 10,63. Hal ini berarti secara klasikal, kemampuan koneksi matematis mahasiswa secara klasikal rata-ratanya masuk dalam predikat E.

Mahasiswa menemui kesulitan ketika menghadapi soal yang berkaitkan dengan indikator mencari hubungan berbagai representasi konsep dan prosedur serta memahami hubungan antartopik matematika. Hal ini sejalan dengan hasil penelitian bahwa peserta didik mampu ketika diminta untuk menuliskan konsep-konsep matematika yang berkaitan dengan masalah yang diselesaikan, tetapi hanya sedikit yang dapat menjelaskan dan menghubungkan alasan penggunaan prosedur konsep tersebut (Lembke \& Reys, 1994).

\section{Profil Kemampuan Penalaran Matematis Mahasiswa}

Tes kemampuan penalaran matematis diikuti oleh 134 mahasiswa. Pada tes ini, nilai terendah yang diperoleh mahasiswa adalah 0 , sedangkan nilai tertingginya adalah 100 . Selanjutnya kemampuan penalaran matematis mahasiswa dianalisis secara deskriptif disajikan pada Tabel 4 ..

Tabel 4. Profil Kemampuan Penalaran Matematis Mahasiswa

\begin{tabular}{ccc}
\hline Nilai & Predikat & $\begin{array}{c}\text { Banyak } \\
\text { Mahasiswa }\end{array}$ \\
\hline $85 \leq$ nilai $\leq 100$ & A & 40 \\
$75 \leq$ nilai $<85$ & AB & 1 \\
$67 \leq$ nilai $<75$ & B & 0 \\
$61 \leq$ nilai $<67$ & BC & 4 \\
$55 \leq$ nilai $<61$ & C & 7 \\
$45 \leq$ nilai $<55$ & CD & 0 \\
$35 \leq$ nilai $<45$ & D & 5 \\
$0 \leq$ nilai $<35$ & E & 77 \\
\hline
\end{tabular}

Berdasarkan Tabel 4, sebanyak 52 mahasiswa mendapat nilai dengan predikat $\mathrm{A}$ sampai dengan C. Hal ini berarti 52 mahasiswa tersebut telah mencapai ketuntasan belajar. Selebihnya, yaitu sebanyak 82 mahasiswa belum mencapai ketuntasan belajarnya pada tes penalaran matematis. Kemampuan penalaran matematis mahasiswa secara klasikal mendapatkan rata-rata nilai 36,93 . Hal ini berarti rata-rata kemampuan penalaran matematis yang dicapai mahasiswa secara klasikal masuk dalam predikat D.

Kemampuan penalaran mahasiswa masih perlu dikembangkan. Hasil penelitian menunjukkan bahwa kemampuan penalaran matematis mahasiswa masih belum baik. Hal ini disebabkan karena mahasiswa kesulitan dalam menalar secara mandiri permasalahan yang diberikan. Mahasiswa terbiasa dengan bimbingan atau dituntun dalam memecahkan masalah, sehingga ketika dihadapkan soal mengenai penalaran matematis mahasiswa merasa 
Himmatul Ulya, Ratri Rahayu, Kartono, dan Isnarto

KEMAMPUAN MATEMATIS MAHASISWA DALAM PENERAPAN ASESMEN KOLABORATIF

REFLEKSI EDUKATIKA : Jurnal Ilmiah Kependidikan 10 (1) Desember 2019. Hlm.113-120

kesulitan. Selain itu mahasiswa belum memiliki rasa ingin tahu terhadap matematika sehingga mahasiswa tidak tertarik menyelesaikan soal yang menuntut untuk bernalar (Akbar, Diniyah, Akbar, Nurjaman, \& Bernard, 2018).

\section{Profil Kemampuan Pemecahan Masalah Matematis Mahasiswa}

Tes kemampuan pemecahan masalah matematis mahasiswa mencapai nilai terendah 0 , sedangkan nilai tertingginya mencapai nilai 100 . Secara rinci profil kemampuan pemecahan masalah matematis mahasiswa berdasarkan predikatnya disajikan pada Tabel 5 berikut.

Tabel 5. Profil Kemampuan Pemecahan Masalah Matematis Mahasiswa

\begin{tabular}{ccc}
\hline Nilai & Predikat & $\begin{array}{c}\text { Banyak } \\
\text { Mahasiswa }\end{array}$ \\
\hline $85 \leq$ nilai $\leq 100$ & $\mathrm{~A}$ & 49 \\
$75 \leq$ nilai $<85$ & $\mathrm{AB}$ & 37 \\
$67 \leq$ nilai $<75$ & $\mathrm{~B}$ & 9 \\
$61 \leq$ nilai $<67$ & $\mathrm{BC}$ & 15 \\
$55 \leq$ nilai $<61$ & $\mathrm{C}$ & 12 \\
$45 \leq$ nilai $<55$ & $\mathrm{CD}$ & 4 \\
$35 \leq$ nilai $<45$ & $\mathrm{D}$ & 1 \\
$0 \leq$ nilai $<35$ & $\mathrm{E}$ & 7 \\
\hline
\end{tabular}

Jika mahasiswa memperoleh predikat A, $\mathrm{AB}, \mathrm{B}, \mathrm{BC}$, dan $\mathrm{C}$, maka mahasiswa dapat dikatakan memenuhi kriteria ketuntasan belajar. Berdasarkan Tabel 5 di atas, mahasiswa yang dapat mencapai ketuntasan belajar minimal sebanyak 122 mahasiswa, sedangkan 12 mahasiswa yang lainnya belum dapat mencapai ketuntasan belajar karena mendapat predikat CD, D, dan E. Secara klasikal, rata-rata kemampuan pemecahan masalah matematis mahasiswa mencapai 76,28. Hal ini berarti rata-rata kemampuan pemecahan masalah matematis mahasiswa secara klasikal masuk dalam predikat $\mathrm{AB}$.

Soal non-rutin yang diberikan pada soal kemampuan pemecahan masalah matematis telah mendorong mahasiswa berpikir tidak seperti biasanya. Soal non-rutin yang diselesaikan mahasiswa memerlukan penyelesaian secara bertahap (Ulya, Kartono, \& Retnoningsih, 2014). Hal ini sesuai dengan definisi kemampuan memecahkan masalah matematis yaitu kemampuan individu dalam menggunakan pengetahuan dan kemampuan yang telah dimiliki sebelumnya untuk disintesis dan diterapkan pada situasi yang baru dan berbeda (Krulik \& Rudnick, 1995).

\section{Profil Kemampuan Berpikir Kritis Matematis Mahasiswa}

Kemampuan berpikir kritis matematis mahasiswa diukur melalui tes uraian dengan pencapaian nilai terendah yang diperoleh adalah 0 , sedangkan nilai tertingginya mencapai nilai 100. Secara rinci profil kemampuan berpikir kritis matematis mahasiswa berdasarkan predikatnya ditunjukkan pada Tabel 6.

Tabel 6. Profil Kemampuan Berpikir Kritis Matematis Mahasiswa

\begin{tabular}{ccc}
\hline Nilai & Predikat & $\begin{array}{c}\text { Banyak } \\
\text { Mahasiswa }\end{array}$ \\
\hline $85 \leq$ nilai $\leq 100$ & A & 64 \\
$75 \leq$ nilai $<85$ & AB & 39 \\
$67 \leq$ nilai $<75$ & B & 2 \\
$61 \leq$ nilai $<67$ & BC & 8 \\
$55 \leq$ nilai $<61$ & C & 8 \\
$45 \leq$ nilai $<55$ & CD & 4 \\
$35 \leq$ nilai $<45$ & D & 3 \\
$0 \leq$ nilai $<35$ & E & 6 \\
\hline
\end{tabular}

Berdasarkan Tabel 6, mahasiswa yang tuntas dalam tes kemampuan berpikir kritis matematis berjumlah 121, sedangkan 13 mahasiswa tidak mencapai ketuntasan belajar minimalnya. Kemampuan berpikir kritis matematis mahasiswa mencapai rata-rata secara klasikal yaitu 77,56. Hal ini berarti bahwa ratarata kemampuan berpikir kritis matematis mahasiswa secara klasikal masuk dalam predikat AB.

Dalam menyelesaikan masalah yang menuntut berpikir kritis mahasiswa dimudahkan dengan soal-soal yang berkaitan dengan etnomatematika. Hal ini sejalan dengan hasil penelitian yang telah dilakukan, yaitu etnomatematika memiliki kaitan dengan indikator kemampuan berpikir kritis, yang meliputi interpretasi, analisis, evaluasi, dan keputusan (Suhartini \& Martyanti, 2017).

\section{Profil Kemampuan Berpikir Kreatif Matematis Mahasiswa
Tes kemampuan berpikir kreatif matematis dilakukan untuk mengukur kemampuan mahasiswa dalam berpikir kreatif matematis. Tes ini diikuti oleh 134 mahasiswa. Nilai terendah yang dicapai pada tes ini adalah 0 , sedangkan nilai tertinggi mencapai nilai 100 .}


Himmatul Ulya, Ratri Rahayu, Kartono, dan Isnarto

KEMAMPUAN MATEMATIS MAHASISWA DALAM PENERAPAN ASESMEN KOLABORATIF

REFLEKSI EDUKATIKA : Jurnal Ilmiah Kependidikan 10 (1) Desember 2019. Hlm.113-120

Selanjutnya kemampuan mahasiswa dianalisis secara deskriptif ditunjukkan pada Tabel 7.

Tabel 7. Profil Kemampuan Berpikir Kreatif Matematis Mahasiswa

\begin{tabular}{ccc}
\hline Nilai & Predikat & $\begin{array}{c}\text { Banyak } \\
\text { Mahasiswa }\end{array}$ \\
\hline $85 \leq$ nilai $\leq 100$ & $\mathrm{~A}$ & 33 \\
$75 \leq$ nilai $<85$ & $\mathrm{AB}$ & 3 \\
$67 \leq$ nilai $<75$ & $\mathrm{~B}$ & 26 \\
$61 \leq$ nilai $<67$ & $\mathrm{BC}$ & 41 \\
$55 \leq$ nilai $<61$ & $\mathrm{C}$ & 8 \\
$45 \leq$ nilai $<55$ & $\mathrm{CD}$ & 2 \\
$35 \leq$ nilai $<45$ & $\mathrm{D}$ & 3 \\
$0 \leq$ nilai $<35$ & $\mathrm{E}$ & 18 \\
\hline
\end{tabular}

Berdasarkan Tabel 7 di atas, sebanyak 111 mahasiswa mencapai ketuntasan belajar dengan ditunjukkan banyaknya mahasiswa yang memperoleh predikat A hingga C. Sisanya, yaitu sebanyak 23 mahasiswa yang lain belum mencapai ketuntasan belajar pada tes kemampuan berpikir kreatif matematis. Secara klasikal, rata-rata kemampuan berpikir kreatif matematis mahasiswa mencapai 64,83 . Hal ini berarti rata-rata kemampuan berpikir kreatif matematis mahasiswa secara klasikal masuk dalam predikat $\mathrm{BC}$.

Penggunaan soal etnomatematika sesuai jika digunakan untuk mengukur keterampilan berpikir kreatif matematika. Peserta didik menyelesaikan masalah dalam tes berpikir kreatif menggunakan berbagai cara berpikir yang dihubungkan dengan pengalamannya sendiri (Lince, 2016).

\section{SIMPULAN}

Hasil penelitian menunjukkan bahwa: (1) kemampuan pemahaman konsep matematis mahasiswa PGSD secara klasikal mencapai ratarata 88,44 dan memperoleh predikat $\mathrm{A}$; (2) ratarata kemampuan komunikasi matematis mahasiswa secara klasikal mencapai 74,54 dan memperoleh predikat $\mathrm{B}$; (3) rata-rata kemampuan koneksi matematis mahasiswa mencapai 10,63 dan memperoleh predikat E; (4) rata-rata kemampuan penalaran matematis mahasiswa secara klasikal memperoleh nilai 36,93 dan memperoleh predikat $\mathrm{D}$; (5) rata-rata kemampuan pemecahan masalah matematis mahasiswa mencapai 76,28 dan memperoleh predikat $\mathrm{AB}$; (6) rata-rata kemampuan berpikir kritis matematis mahasiswa secara klasikal mencapai 77,56 dan memperoleh predikat $\mathrm{AB}$; dan (7) rata-rata kemampuan berpikir kreatif matematis mahasiswa mencapai 64,83 dan memperoleh predikat $\mathrm{BC}$.

\section{DAFTAR PUSTAKA}

Akbar, G. A. M., Diniyah, A. N., Akbar, P., Nurjaman, A., \& Bernard, M. (2018). Analisis Kemampuan Kemampuan Penalaran dan Self Confidence Siswa SMA dalam Materi Peluang. Journal On Education, 1(1), 14-21.

Arisetyawan, A., Suryadi, D., Herman, T., \& Rahmat, C. (2014). Study of Ethnomathematics: A Lesson From The Baduy Culture. Journal of Education and Research, 2(10), 681-688.

Ashraf, H., \& Zolfaghari, S. (2018). EFL Teachers' Assessment Literacy and Their Reflective Teaching. International Journal of Instruction, 11(1), 425-436.

Dandis, M. A. (2013). The Assessment Methods That Are Used in A Secondary Mathematics Class. Jurnal for Educators, Teachers and Trainers, 4(2), 133-143.

Fajri, M. (2017). Kemampuan Berpikir Matematis dalam Konteks Pembelajaran Abad 21 di Sekolah Dasar. Lemma, III(2), $1-11$.

Falchikov. (2005). Improving Assessment through Student Involvement. Practical Solutions for Aiding Learning in Higher Further Education. New York: Routlege Falmer.

Fouze, A. Q., \& Amit, M. (2018). Development of Mathematical Thinking through Integration of Ethnomathematic Folklore Game in Math Instruction. EURASIA Journal of Mathematics, Science and Technology Education, 14(2), 617-630.

Joseph, Y. K. K. (2011). An Exploratory Study of Primary Two Pupils' Approach Journal of Mathematics Education to Solve Word Problems. Journal of Mathematics Education, 4(1), 19-30.

Kartono, Winarti, E. R., \& Masrukan. (2016). The Effect of Collaborative Assessment 
Himmatul Ulya, Ratri Rahayu, Kartono, dan Isnarto

KEMAMPUAN MATEMATIS MAHASISWA DALAM PENERAPAN ASESMEN KOLABORATIF

REFLEKSI EDUKATIKA : Jurnal Ilmiah Kependidikan 10 (1) Desember 2019. Hlm.113-120

Implementation in Cooperative Learning to Improve The Students' Mathematical Disposition and Self-Regulated Learning. International Journal of Advance Research and Innovative Ideas in Education, 2(3), 80-86.

Kemenristekdikti. (2015). Permenristekdikti Nomor 44 Tahun 2015 tentang Standar Nasional Perguruan Tinggi. Jakarta: Kemenristekdikti.

Khodabakhshzadeh, H., Kafi, Z., \& Hosseinnia, M. (2018). Investigating EFL Teachers' Conceptions and Literacy of Formative Assessment: Constructing and Validating an Inventory. International Journal of Instruction, 11(1), 139-152.

Krulik, S., \& Rudnick, J. A. (1995). The New Sourcebook for Teaching Reasoning and Problem Solving in Elementary School. Boston: Allyn and Bacon.

Lembke, L. O., \& Reys, B. . (1994). The Development of, and Integration Between, Initiative and School-Taught Ideas about Percent J. Res. Journal for Research in Mathematics Education, 25(3), 237-259.

Lince, R. (2016). Creative Thinking Ability to Increase Student Mathematical of Junior High School by Applying Models Numbered Heads Together. Journal of Education and Practice, 7(6), 206-212.

Musfiqi, S., \& Jailani. (2014). Pengembangan Bahan Ajar Matematika yang Berorientasi pada Karakter dan Higher Order Thinking Skill (HOTS). PYTHAGORAS: Jurnal Pendidikan Matematika, 9(1), 45-59.

Rahayu, R., Ulya, H., Kartono, \& Isnarto. (2019). A Practicallity Analysis Of Collaborative Assessment Model Based On Ethnomathematics. Journal of Advanced Research in Dynamical and Control Systems, 11(7), 366-373.

Rahayu, R., Ulya, H., Kartono, Isnarto, \& Kurniasih, N. (2018). Collaborative Assessment Using QR-Code on Ethnomathematics Learning for Pre-
Service Teacher. International Journal of Engineering \& Technology, 7(2.13), 413417.

Rasi, H., Kuivila, H., Pölkki, T., Bloigu, R., Rintamäki, H., \& Tourula, M. (2017). A Descriptive Quantitative Study of 7- and 8-Year-Old Children's Outdoor Recreation, Cold Exposure and Symptoms in Winter in Northern Finland. International Journal of Circumpolar Health, 76(1), 1-7.

Rosa, M., \& Orey, D. C. (2011). Ethnomathematics: The Cultural Aspects of Mathematics. Revista Latinoamericana de Etnomatemática, 4(2), 32-54.

Suhartini, \& Martyanti, A. (2017). Meningkatkan Kemampuan Berpikir Kritis Pada Pembelajaran Geometri Berbasis Etnomatematika. Jurnal Gantang, II(2), 105-112.

Sumarmo, U. (2012). Pendidikan Karakter serta Pengembangan Berfikir dan Disposisi Matematik dalam Pembelajaran Matematika. Prosiding Seminar Pendidikan Matematika Di NTT, 1-26.

Sumaryanta. (2018). Penilaian HOTs dalam Pembelajaran Matematika. Indonesian Digital Journal of Mathematics and Education, 8(8), 500-509.

Ulya, H. (2016). Pembelajaran Matematika Berbasis Etnomatematika untuk Membangun Karakter Cinta Tanah Air dan Kreativitas Belajar Matematika. Prosiding Seminar Nasional Psikologi, 29-39.

Ulya, H., Kartono, \& Retnoningsih, A. (2014). Analysis of Mathematics Problem Solving Ability of Junior High School Students Viewed From Students' Cognitive Style. International Journal of Education and Research, 2(10), 577-582.

Umar, W. (2012). Membangun Komunikasi Matematis dalam Pembelajaran Matematika. Infinity Jurnal Ilmiah Program Studi Matematika STKIP Siliwangi Bandung, 1(1), 1-9. 
Himmatul Ulya, Ratri Rahayu, Kartono, dan Isnarto

KEMAMPUAN MATEMATIS MAHASISWA DALAM PENERAPAN ASESMEN KOLABORATIF

REFLEKSI EDUKATIKA : Jurnal Ilmiah Kependidikan 10 (1) Desember 2019. Hlm.113-120

Wijayanto, A. D., Fajriah, S. N., \& Anita, I. W. (2018). Analisis Kemampuan Komunikasi Matematis Siswa SMP Pada Materi Segitiga dan Segiempat. Journal Cendekia: Jurnal Pendidikan Matematika, 2(1), 97-104.
Williams, C. (2007). Research Methods. Journal of Business \& Economic Research, 5(3), 65-72. 